\title{
PELAKSANAAN PROGRAM PENDEKATAN KEAGAMAAN MELALUI KKN STIBA MAKASSAR DI DESA BARUGA KABUPATEN MAROS
}

\author{
Asnawati Patuti \\ Sekolah Tinggi Ilmu Islam dan Bahasa Arab (STIBA) Makassar \\ asnawati@stiba.ac.id \\ Rahmat \\ Sekolah Tinggi Ilmu Islam dan Bahasa Arab (STIBA) Makassar \\ rahmatar09@gmail.com
}

\section{Keywords : \\ Da'wah, Baruga Village, \\ Maros, KKN, Society.}

\begin{abstract}
Baruga village, Bantimurung sub-district is an area in Maros district where the majority of the original population is Muslim. The existence of Islam in Maros had been around for quite a long time with the entry of King of Gowa and Tallo who possessed an area bordering the Kingdom of Marusu, Maros that the Islamic life of the Baruga Village Community, Bantimurung district, Maros is so prominent. The purpose of the Community Service Program (KKN) III STIBA Makassar was to perform community service which is one of the pillars of the tri dharma of higher education. The method of implementing this program begins with conducting a field review based on an independent instrument. The results of the KKN program show the importance of community service programs with regards to the benefits found by KKN participants, the community, and the government. Religious activities which are the main orientation of this program have been successfully held, as well as social activities, organizational activities, and the active role of $K K N$ participants with the government in the efforts of developing a successful community.
\end{abstract}

Kata kunci :
Dakwah, Desa baruga,
Maros, KKN, Masyarakat.

Desa Baruga kecamatan Bantimurung adalah satu wilayah yang berada dalam kabupaten Maros yang mayoritas penduduk aslinya adalah muslim. Keberadaan islam di Maros sudah cukup lama yaitu dengan masuk islamnya Raja Gowa dan Tallo yang memiliki wilayah perbatasan langsung dengan kerajaan marusu maros sehingga kehidupan berislam Masyarakat Desa Baruga kecamatan Bantimurung Maros nampak begitu nyata. Tujuan Kuliah Kerja Nyata (KKN) III Stiba Makassar adalah untuk mewujudkan pengabdian kepada masyarakat yang merupakan salah satu pilar tri dharma perguruan tinggi. Metode pelaksanaan program ini diawali dengan melakukan tinjauan lapangan berdasarkan instrumen mandiri. Hasil program KKN menunjukkan pentingnya program pengabdian kepada masyarakat dengan melihat manfaat yang dirasakan oleh peserta KKN, masyarakat dan pemerintah. Kegiatankegiatan keagamaan yang menjadi orientasi utama program ini berhasil terlaksana, begitupula dengan kegiatan sosial, kegiatan organisasi serta peran aktif peserta KKN dengan pemerintah dalam upaya pengembangan masyarakat sukses dilaksanakan. 


\section{PENDAHULUAN}

\section{Profil Desa Baruga}

Desa Baruga merupakan salah satu Desa yang terletak di Kecamatan Bantimurung, Kabupaten Maros dengan luas wilayah 52,51 km2. Sebelah timur Desa Baruga berbatasan dengan Desa Tukamasea, sebelah utaranya berbatasan dengan Kabupaten Pangkep, sebelah baratnya berbatasan dengan Desa Salenrang dan sebelah selatan berbatasan dengan Desa Mattoanging. Berdasarkan SK Bupati Kepala Daerah Kabupaten Maros tentang pembentukan Dusun dalam wilayah Desa dan lingkungan, maka Desa Baruga dibagi atas 5 dusun yakni Dusun Kassi, Cambajawa, Batunapara, Samariga dan Balang.

Desa baruga seperti pada umumnya Desa-desa lain di kecamatan Bantimurung mempunyai iklim kemarau, pancaroba dan penghujan. Hal tersebut mempunyai pengaruh langsung terhadap pola tanam yang ada di Desa Baruga beserta Desa lain di Kecamatan Bantimurung. Berdasarkan data curah hujan selama lima tahun terakhir adalah tipe iklim tropis menurut Olderman maka terdapat dua tipe yaitu:

1. Tipe c. 2 adalah bulan basah 2-5 bulan dan bulan kering 2-3 bulan

2. Tipe c.3 adalah bulan basah 5-6 bulan dan bulan kering 3-5 bulan

Bulan basah umumnya jatuh pada bulan November sampai bulan April, sedangkan bulan kering jatuh pada bulan Mei sampai Oktober. Berkaitan dengan temperatur udara, maka informasi yang tercatat adalah berkisar antara 25 sampai 35 derajat celcius sehingga dapat dikatakan bahwa yang terendah pada musin hujan dan tertinggi pada musim kemarau.

Desa Baruga merupakan salah satu desa di wilayah Kecamatan Bantimurung memiliki jumlah penduduk sebanyak 4490 jiwa yang terdiri dari laki-laki 2280 jiwa perempuan 2210 jiwa dari jumlah kepala keluarga sebanyak $1111 \mathrm{KK}$. Keyakinan yang dianut oleh seluruh masyarakat di Desa Baruga adalah agama Islam. Struktur penduduk Desa Baruga dapat diuraikan sebagai berikut ${ }^{1}$ :

Tabel 1. Jumlah penduduk Desa Baruga berdasarkan jenis kelamin dan Dusun

\begin{tabular}{clccc}
\hline \multirow{2}{*}{ No. } & \multirow{2}{*}{ Dusun } & \multicolumn{2}{c}{ Jenis kelamin } & \multirow{2}{*}{ Jumlah } \\
\cline { 3 - 4 } & & Laki-laki & Perempuan & \\
\hline 1. & Kassi & 155 & 168 & 323 \\
\hline 2. & Cambajawa & 458 & 439 & 897 \\
\hline 3. & Batunapara & 990 & 912 & 1.902 \\
\hline 4. & Samariga & 322 & 308 & 630 \\
\hline 5. & Balang & 355 & 384 & 738 \\
\hline
\end{tabular}

\footnotetext{
${ }^{1}$ Sumber : Buku perkembangan penduduk Desa Baruga tahun 2018
} 
WAHATUL MUJTAMA': Jurnal Pengabdian Masyarakat

Vol. 1, No. 2 (2020) : Hal. 185-199

Website: https://journal.stiba.ac.id

Tabel 2. Jumlah penduduk berdasarkan kepala keluarga (KK) di Desa Baruga

\begin{tabular}{clcc}
\hline No. & \multicolumn{1}{c}{ Dusun } & Jumlah KK & jumlah \\
\hline 1. & Kassi & 81 & 81 \\
\hline 2. & Cambajawa & 233 & 233 \\
\hline 3. & Batunapara & 441 & 441 \\
\hline 4. & Samariga & 160 & 160 \\
\hline 5. & Balang & 196 & 196 \\
\hline & jumlah & 1111 & 1111
\end{tabular}

Tabel 3. Kepadatan penduduk di Desa Baruga

\begin{tabular}{llcc}
\hline No. & Dusun & Jumlah Penduduk (Jiwa) & ket \\
\hline 1. & Kassi & 323 \\
\hline 2. & Cambajawa & 897 & \\
\hline 3. & Batunapara & 1.902 \\
\hline 4. & Samariga & 630 \\
\hline 5. & Balang & 738 \\
\hline
\end{tabular}

\section{Potensi Lokal Desa Baruga}

\section{Keadaan Ekonomi}

Mata pencaharian masyarakat Desa Baruga didominasi oleh aktifitas pertanian. Hal tersebut dapat dilihat bahwa sebagian besar wilayah desa diperuntukkan untuk lahan pertanian. Di antara hasil pertanian yang ada di Desa Baruga yakni yang paling besar menyumbang pendapatan adalah hasil pertanaman Padi dan Palawija. Hasil pertanian lain yang dijadikan sebagai komoditi perdagangan adalah pisang, jagung, sereh, lengkuas, kedelai, gabah serta berbagai jenis hasil tanaman sayur-sayuran. Selain hasil bumi, mata pencaharian masyarakat Desa Baruga mencakup hasil peternakan berupa sapi, kambing, ayam, dan itik. Adapun sarana prasarana Desa yang ada sebagai penopang ekonomi masyarakat yaitu sarana transportasi; seperti jalanan Cor beton (sekitar $13 \mathrm{Km}$ ), jalan tanah $2 \mathrm{Km}$ serta saluran irigasi sepanjang $5 \mathrm{Km}$, jembatan Tani, kemudian di tambah dengan aliran sungai sepanjang $10 \mathrm{Km}$.

Selain bertani, sebagian masyarakat Desa Baruga bekerja di PT. Semen Bosowa. Dengan adanya perusahaa ini, masyarakat lebih mudah mendapatkan pekerjaan yang tidak jauh dari kampung halaman bisa lebih meningkatkan perekonomian keluarganya tanpa bergantung pada pertanian saja yang terkadang hasilnya tidak menentu. Namun begitu, sebagian masyarakat Desa Baruga ada juga yang merantau di luar pulau seperti Papua. Dan beberapa dari perantau tersebut yangg usahanya berhasil di daerah perantauannya, mengajak keluarga dan kerabatnya bergabung dan ikut merantau bersama mereka. 
WAHATUL MUJTAMA': Jurnal Pengabdian Masyarakat

Vol. 1, No. 2 (2020) : Hal. 185-199

Website: https://journal.stiba.ac.id

\section{Keadaan Sosial}

Ciri khas masyrakat desa baruga adalah masyarakat yang religius dan masih melekat adanya rasa hidup gotong-royong yang berbaur dengan adat istiadat yang mewarnai kehidupan masyarakat Desa Baruga. Hal tersebut dapat dilihat bahwa sebagian besar masyarakat Desa Baruga memeluk agama Islam. Sementara komunitas yang sadar akan sunnah bisa ditemukan di perumahan Bosowa (sebagian besar bukan penduduk asli/para pendatang) dengan beberapa kajian rutinnya. Di samping itu, ada sebagian kecil pemeluk kristen. Setiap dusun memiliki tempat ibadah berupa masjid yang dibangun dengan swadaya masyarakat serta ditambah dengan dana ADD pemerintah Desa Baruga. Kebiasaan masyarakat yang turun temurun atau adat istiadat masyarakat masih sangat melekat dalam kehidupan bermasyarakat dan itu menjadi salah satu motivasi kerja bagi sebagaian masyarakat khususnya para petani di Desa. Tradisi yang ada dipelihara dan dijadikan sebagai wadah mempererat persatuan dan kebersamaan dalam kehidupan bermasyarakat di Desa Baruga, baik yang tinggal di dalam desa maupun di daerah perantauan dan juga dapat menumbuhkan etos kerja bagi masyarakat

\section{Kesehatan}

Dalam memenuhi tingkat kebutuhan masyarakat akan pelayanan kesehatan, maka Pemerintah Kabupaten Maros telah membangun fasilitas pelayanan kesehatan di Desa Baruga yaitu Puskesmas Pembantu (PUSTU). Pustu ini sangat berfungsi dengan baik dalam melayani masyarakat seperti pemeriksaan kesehatan, pemberian obat oleh tenaga medis yang bertugas kepada pasiesn serta kadang dijadikan sebagai tempat rawat inap bagi pasien yang tidak terlalu parah penyakitnya dan butuh perawatan yang intensip serta digunakan untuk pemeriksaan bagi para lansia. Selain PUSTU di Desa Baruga, juga terdapat Pos Pelayanan Terpadu (POSYANDU) yang telah dibangun oleh Pemerintah Desa Baruga melalui anggaran dana ADD. Fasilitas ini digunakan untuk tempat pelayanan kesehatan masyarakat, seperti penimbangan Balita, vaksinasi, serta pemeriksaan para manula.

\section{PEMBAHASAN}

\section{Taklim Muslimah}

Taklim muslimah adalah salah satu program kerja mahasiswi KKN Angkatan III STIBA Makassar yang dikhususkan bagi muslimah dan diisi dengan ceramah agama. Majelis Taklim memiliki peran yang strategis dalam pembentukan kepribadian muslimah. ${ }^{2}$ Oleh karena itu, majelis taklim perlu dikemas dalam berbagai kegiatan nyata

\footnotetext{
${ }^{2}$ Mariam, M. (2019). PERAN MAJELIS TAKLIM DALAM PEMBERDAYAAN UNTUK MEMBENTUK KEPRIBADIAN MUSLIMAH. Lembaran Masyarakat: Jurnal Pengembangan Masyarakat Islam, 5(02), 121-136.
} 
WAHATUL MUJTAMA': Jurnal Pengabdian Masyarakat

Vol. 1, No. 2 (2020) : Hal. 185-199

Website: https://journal.stiba.ac.id

yang aplikatif dalam keseharian dan tidak hanya sebatas pada kegiatan keilmuan (tataran kognitif). Majelis Taklim diharapkan sebagai kawah candra dimuka pembentukan kepribadian yang bersahaja. ${ }^{3}$ Kegiatan ini secara khusus bertujuan untuk menjalin silaturahmi dengan penduduk desa khususnya kaum muslimah melalui pendekatan islam dengan memberikan siraman rohani serta ilmu Islam sebagai bentuk pengabdian dan pengamalan ilmu dari mahasiswa STIBA Makassar.

Kegiatan ini dilakukan dengan target setiap dusun dan telah terlaksana dengan baik di tiga masjid dan satu mushalla. Kegiatan ini dimulai dengan tilawah, penyampaian materi yang berbeda di setiap tempat, kemudian ditutup dengan tanya jawab. Diantara pengalaman menarik selama program ini berlangsung adalah ibu-ibu Dusun Batunapara yang turut berpartisipasi membawa konsumsi serta kehadiran Ibu desa di dua tempat taklim.

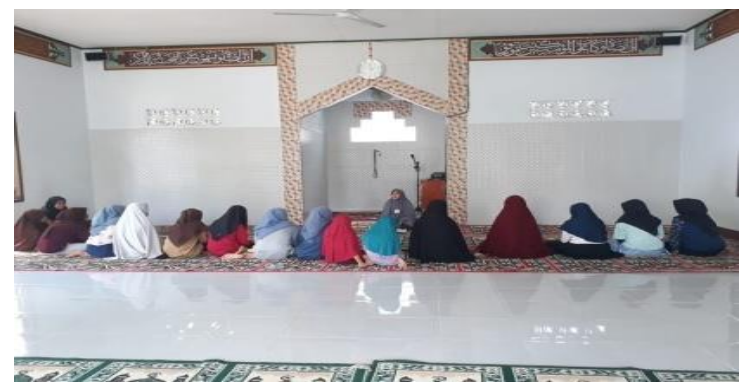

Gambar 1. Taklim Muslimah

Kegiatan ini didukung oleh adanya ikatan emosional dengan ibu-ibu setiap dusun yang dijalin lewat DIROSA dan silaturahim, membuat mereka tetap hadir di taklim muslimah. Sulitnya perizinan di Masjid Samariga, dan warga yang cukup sensitif dengan "salaf" merupakan kendala dalam kegiatan ini sehingga harus mengganti judul taklim. Kurangnya publikasi dan silaturahim di Dusun Kassi, karena daerah yang cukup jauh. Tindakan solutif dari kendala tersebut adalah berupaya untuk mengintensifkan silaturahim dengan warga.

\section{Kajian Jum'at}

Kajian Jum'at (KAMAT) merupakan suatu kegiatan yang berorientasi pada remaja kalangan SMP/Sederajat dan SMA/Sederajat. KAMAT menjadi salah satu agenda kerja mahasiswi KKN Ang. III STIBA Makassar yang bertujuan untuk menambah wawasan keislaman para remaja. Kajian rutin merupakan agenda yang perlu untuk ditumbuhkan di tengah masyarakat karena masyarakat biasanya abai dengan kegiatan

\footnotetext{
${ }^{3}$ Riswana, R. (2018). Peranan Taklim Muslimah dalam Meningkatkan Pemahaman Hak dan Kedudukan Wanita dalam Rumah Tangga (Studi pada Yayasan Markaz Imam Malik Kota Makassar) (Skripsi, Universitas Islam Negeri Alauddin Makassar).
} 
dakwah disebabkan aktivitas yang padat dalam keseharian (bekerja dan belajar). ${ }^{4}$ Apalagi dewasa ini kebutuhan untuk mempelajari dan memahami ilmu agama terlihat semakin besar. Ada kerinduan masyarakat untuk memahami ajaran agama secara baik dan mendekatkan dirinya pada Tuhan. Dalam kondisi demikian, keberadaan para da iei (juru dakwah) yang berfungsi untuk memaparkan ajaran Islam kepada khalayak menjadi sangat signifikan. ${ }^{5}$

Kegiatan ini terlaksana di MTS/MA As-Sakinah dan MDIA Miftahussalam pada hari jum'at setelah pulang sekolah di mushallah sekolah dan ruang kelas. Metode KAMAT dilakukan dengan menggunakan metode ceramah dan tanya jawab di akhir dengan durasi dalam setiap pertemuan berkisar antara 45 menit sampai 1 jam. Cerita menarik pada pelaksanaan program ini adalah adanya pemateri yang sudah tiba di sekolah, namun harus kembali pulang ke posko karena akses menuju lokasi yang terdampak banjir.

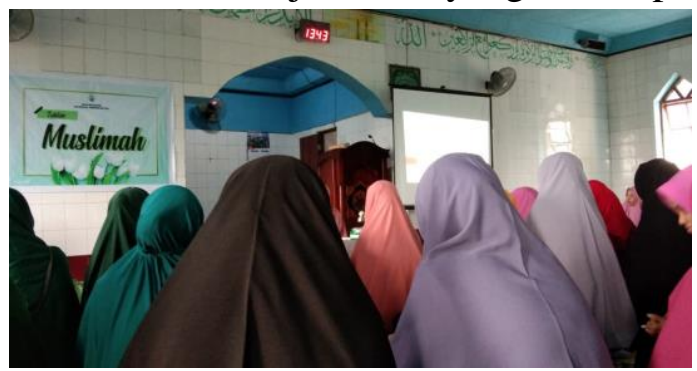

Gambar 1.3. Kajian Jum'at

Kegiatan ini didukung dengan respon positif para siswi dalam menerima materi serta antusias dalam berpartisipasi selama kegiatan ini berlangsung. Hambatan dalam kegiatan ini adalah akses lokasi yang terdampak banjir menyebabkan program tidak berjalan beberapa kali serta komunikasi yang terjalin tidak begitu baik antara pelaksana dan para siswi. Tindakan solutif dari hal tersebut adalah berupaya untuk menjalin komunikasi yang baik antara pelaksana, guru dan siswa agar kegiatan dapat berjalan dengan baik dan lancar.

\section{DIROSA}

Pendidikan Alquran Orang Dewasa (DIROSA) merupakan salah satu agenda kerja mahasisiwi KKN Angkatan III STIBA Makassar yang berorientasi pada orang dewasa dan usia lanjut. DIROSA merupakan sebuah metode praktis pengajaran membaca Alquran yang diperuntukkan khusus kepada kaum remaja dan orang tua, program ini berjalan secara dinamis dan sistematis, dilaksanakan selama kurung waktu tertentu

\footnotetext{
${ }^{4}$ Widyanto, R. A., Widiyanto, A., \& Arfan, M. Penerapan M-Dakwah Pada Kelompok Kajian Jum'at Pagi Sebagai Sarana Dakwah Alternatif.

${ }^{5}$ Nadhifa, S. B. (2017). Pemahaman Jamaah Terhadap Pesan Dakwah Ustadz. Abdullah Zaen, Lc., M.A dalam Pengajian Rutin Jum'at Pagi Di Masjid Agung Darussalam Purbalingga (Skripsi, IAIN Purwokerto)
} 
WAHATUL MUJTAMA': Jurnal Pengabdian Masyarakat

Vol. 1, No. 2 (2020) : Hal. 185-199

Website: https://journal.stiba.ac.id

dengan materi yang berjenjang, Metode Dirosa merupakan penggabungan pola pengajaran membaca al-Qur'an dan ilmu-ilmu keislaman. ${ }^{6}$

DIROSA bertujuan untuk memperbaiki bacaan Alquran dan upaya agar warga dekat dengan Alquran. Secara khusus, tujuan pelaksanaan program DIROSA dalam pelaksanaan KKN STIBA Makassar adalah; (1) Meningkatkan semangat dalam mempelajari dan mengajarkan Alqur'an bagi remaja dan orang dewasa, (2) Memberikan pembelajaran baca Alqur'an kepada remaja dan orang dewasa agar dapat membaca Alqur'an sesuai ilmu tajwid. (3) Memberikan tambahan ilmu dasar-dasar keislaman kepada remaja dan orang dewasa. ${ }^{?}$

Keberadaan kegiatan DIROSA diharapkan dapat memberantas buta huruf aksara Alquran masyarakat Desa Baruga. Kegiatan DIROSA berlangsung 2-3 kali perpekan. Pertemuan pertama diisi dengan perkenalan, penyepakatan waktu, dan pembagian buku DIROSA bagi yang belum memiliki buku. Metode pengajaran DIROSA dilakukan dengan menggunakan nada khusus yang bertujuan agar peserta cepat paham dan ingat dengan apa yang diajarkan serta mengurangi tingkat kebosanan ibu-ibu dalam mempelajarinya. Durasi pertemuan berkisar antara $1-1,5$ jam dengan agenda membaca, mendengar, dan praktik pelafalan huruf- huruf hijaiyah dengan benar. Bahkan, terkadang pengajar harus menuliskan dan menjelaskan satu demi satu huruf hijaiyah. Pengalaman menarik dari kegiatan ini adalah pengajar yang terkadang lupa dengan nada materi yang akan diajarkan serta ibu- ibu usia lanjut yang sulit mengucapkan beberapa huruf hijaiyah sehingga harus diberikan pengajaran maksimal.

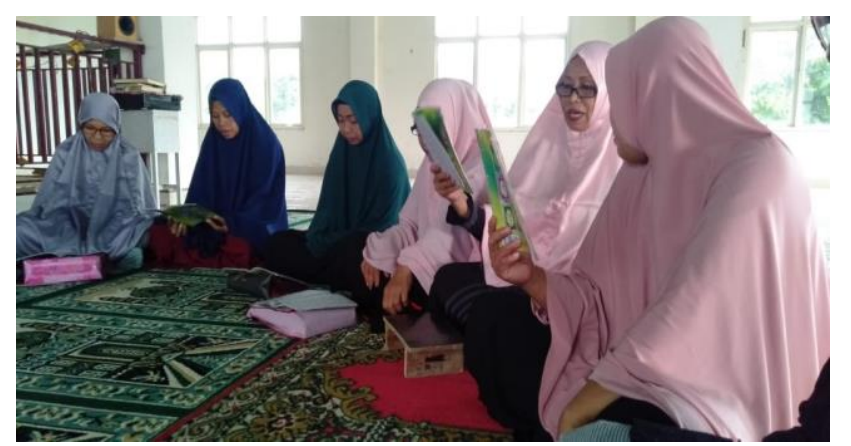

Gambar 1.4. DIROSA

Kegiatan ini didukung oleh respon positif ibu-ibu dalam mempelajari Alquran dengan metode DIROSA yang dibuktikan dengan banyaknya kelompok DIROSA yang dibentuk serta antusias ibu-ibu dalam mengikuti DIROSA bahkan terkadang meminta

\footnotetext{
${ }^{6}$ Muhammad Saddang, Achmad Abu Bakar, Munir. Implementasi Metode DIROSA dalam Pembelajaran Al-Qur'an Dewan Pimpinan Daerah Wahdah Islamiyah Makassar, (Makassar: Jurnal Diskursus Islam, Vol.6, N0.3 (2018): h.486

${ }^{7}$ Wijaya, H. (2020). Pembelajaran Metode Dirosa di Desa Majannang Kabupaten Gowa. WAHATUL MUJTAMA': Jurnal Pengabdian Masyarakat, 1(1), 67-74. Hal. 70
} 
WAHATUL MUJTAMA': Jurnal Pengabdian Masyarakat

Vol. 1, No. 2 (2020) : Hal. 185-199

Website: https://journal.stiba.ac.id

waktu lebih. Kendala yang ditemukan dalam kegiatan ini adalah sulitnya mengatur waktu yang tepat antara pengajar dan peserta, hal ini dikarenakan bertepatan dengan waktu pelaksanaan program kerja lainnya. Solusinya adalah dengan mengatur jadwal dan agenda program kerja sebaik-baiknya dengan mengantisispasi adanya jadwal kegiatan yang bersamaan.

\section{Pengajaran Tahsinu Qira'atil Qur'an}

Pembelajaran Tahsin adalah proses memperbaiki bacaan Alquran, mengenalkan makhraj huruf dan hukum-hukum bacaan. Al-Qur'an merupakan kitab suci umat Islam sehingga umat Islam diperintahkan untuk membaca, mengamalkan, dan mempelajarinya, sebagai bentuk pengagungan kepada Al Qur'an. ${ }^{8}$ Tahsin diajarkan kepada anak-anak, remaja dan ibu-ibu. Kegiatan ini bertujuan untuk mengenalkan makhraj huruf hijaiyyah sehingga mampu membedakan penyebutan setiap huruf dan mampu membaca Alquran dengan benar sesuai ilmu tajwid. Mempelajari Al-Qurean ini sangat penting sekali dalam kehidupan sehari-hari, karena Al-Qureean merupakan wahana untuk meningkatkan dan membangun kualitas sumber daya manusia dalam beragama. ${ }^{9}$

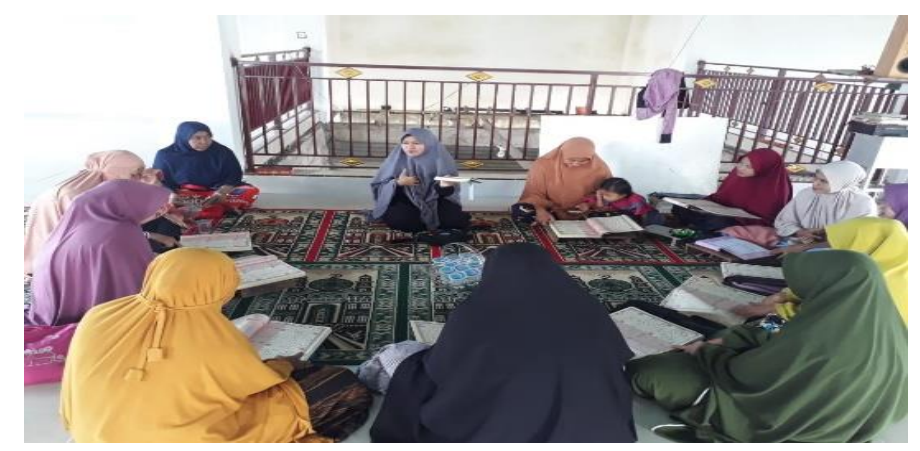

Gambar 1.5. Pengajaran Taḥsīnu qirātil qurān

Halaqah tahsin dilakukan 2-3 kali setiap pekannya sesuai dengan kesepakatan antara pengajar dan peserta di posko, rumah warga dan masjid. Pertemuan perdana diisi dengan perkenalan, penyepakatan waktu, memberi motivasi dan pencerahan untuk mempelajari Alquran. Metode pengajaran tahsin seperti pada umunya, yaitu memaparkan dengan jelas makharijul huruf sehingga peserta mampu menyebutkan dan membedakan penyebutan setiap huruf dengan baik. Sebelum majelis ditutup, setiap peserta digilir untuk membaca ayat-ayat Alquran sehingga kesalahan-kesalahan bisa diperbaki. Pengalaman menariknya adalah Ibu-ibu yang selalu ceria saat sedang berhalaqah sehingga halaqah tidak sepi dan membosankan.

\footnotetext{
${ }^{8}$ Arobi, M. (2019). Rumah-Rumah Tahfizh di Kota Banjarmasin: Profil, Program, dan Metode Pengajaran Al-Qur'an. Tarbiyah: Jurnal Ilmiah Kependidikan, 8(1), 39-52. Hal 39

${ }_{9}^{9}$ Guswenti, M. (2019). Implementasi Metode Dirosa Dalam Pembelajaran Membaca Al-Qur'an Bagi Santri Di Wahdah Islamiyah Bengkulu (Skripsi, IAIN Bengkulu). Hal.2
} 
WAHATUL MUJTAMA': Jurnal Pengabdian Masyarakat

Vol. 1, No. 2 (2020) : Hal. 185-199

Website: https://journal.stiba.ac.id

Pendukung utama kegiatan ini adalah warga yang sangat antusias untuk mempelajari Al-quran. Kendala yang tercatat pada kegiatan ini adalah sulitnya mencari pengganti pengajar saat pengajar sedang sakit atau berhalangan. Tindakan solutif dari kendala ini adalah membuat tahsin online.

\section{Jalan Santai}

Jalan santai merupakan suatu kegiatan yang dapat meningkatkan kesehatan fisik dan juga kesehatan mental. Kegiatan ini diorientasikan kepada anak-anak agar dapat memahami serta memaknai nikmat yang telah Allah berikan kepada hamba-Nya dan juga kegiatan ini dapat meningkatkan kesehatan.

Kegiatan jalan santai berlangsung setiap hari Ahad. Peserta KKN ikut serta dalam kegiatan ini, baik pagi maupun sore setiap hari Ahad dengan santri TK/TPA yang berbeda setiap pekannya. Pengalaman menariknya adalah peserta KKN dan anak-anak yang ikut dapat mengunjungi bebrapa tempat yang belum pernah dikunjungi sebelumnya.

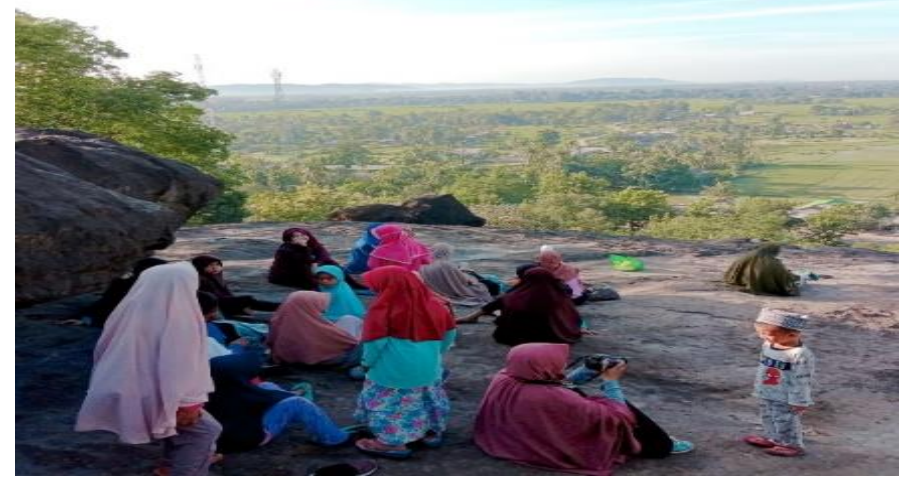

Gambar 1.6. Jalan Santai

Faktor pendukung pelaksanaan kegiatan ini adalah respon positif dari orang tua peserta dan masyarakat setempat kepada peserta KKN sebagai pelaksana serta antusias dan keceriaan anak-anak saat mengikuti kegiatan ini. Kendala yang ditemukan adalah beberapa peserta didik selalu mengganggu temannya ketika proses jalan santai berlangsung. Solusinya adalah menasehati secara khusus dan merangkul peserta didik yang selalu mengganggu temannya.

\section{Ramah Tamah}

Ramah tamah Muslimah se-Baruga merupakan salah satu kegiatan insidental mahasiswi KKN angkatan III STIBA Makassar yang berorientasi pada ibu-ibu DIROSA dan tahsin mahasiswi KKN tahun 2020 di Desa Baruga. Kegiatan ini bertujuan untuk mempererat silaturahmi ibu-ibu DIROSA dan tahsin di semua dusun Desa Baruga. Kegiatan ini juga sekaligus sebagai ajang perpisahan mahasiswi KKN dengan ibu-ibu. Kegiatan ini dilaksanakan sekali selama masa KKN Ang. III mahasiswi STIBA Makassar yaitu pada hari Jum'at, 21 Februari 2020 pukul 09.00-13.30 WITA di Masjid H. Mahmud 
WAHATUL MUJTAMA': Jurnal Pengabdian Masyarakat

Vol. 1, No. 2 (2020) : Hal. 185-199

Website: https://journal.stiba.ac.id

perumahan Bosowa dengan judul "Bertemu Karena Alquran, Bersama Hingga JannahNya". Sasaran utama kegiatan ini adalah ibu-ibu yang telah aktif mengikuti DIROSA dan tahsin. Yang menarik pada kegiatan ini adalh adanya tangisan antar peserta dan mahasiswi KKN serta kehadiran Ibu Desa yang turut menyukseskan acara ini.

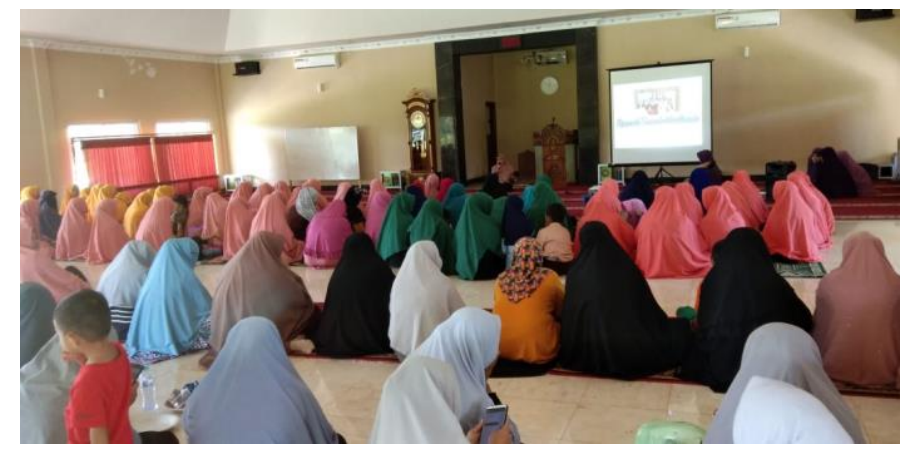

Gambar 1.7. Ramah Tamah

Kegiatan ini mendapat dukungan penuh dan respon positif dari Masyarakat setempat kepada mahasiswi KKN, hal itu terlihat dari semangat ibu-ibu menghadiri kegiatan ramah tamah ini serta antusias peserta selama kegiatan berlangsung. Kendala yang dujumpai dalam kegiatan ini adalah sulitnya mengatur waktu antara pemateri dan waktu yang telah disusun disebabkan karena jadwal mengajar yang bertabrakan serta jarak yang cukup jauh. Solusinya adalah mempersiapkan waktu yang tidak bertabrakan dengan pemateri dan tidak mengharap pada satu pemateri saja.

\section{Pengajaran Agama Islam dan Bahasa Arab}

Pembelajaran Agama Islam dan Bahasa Arab merupakan kegiatan yang dititikberatkan di sekolah- sekolah yang ada di Desa Baruga. Kegiatan ini bertujuan agar siswa dapat memahami Alquran dan Hadis sebagai sumber hukum ajaran Islam dan menambah wawasan ilmu tentang kosa kata bahasa Arab.

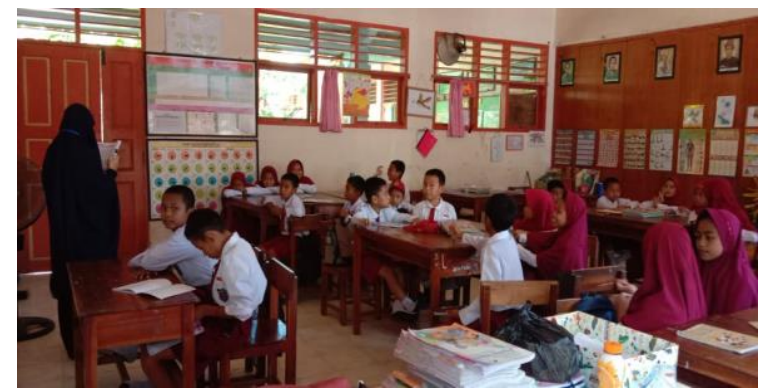

Gambar 1.8. Pengajaran Agama Islam dan Bahasa Arab

Kegiatan ini berlangsung selama masa KKN di beberapa sekolah, antara lain: SDN 243 Baruga Dusun Balang, SDN 189 Baruga Dusun Camba Jawa, SDN 191 Baruga 
Dusun Batunapara dan Madrasah Tsanawiyah Miftahussalam Dusun Samariga. Diawali dengan silaturahim ke sekolah-sekolah kemudian membuat surat izin untuk mengajar dan membawanya ke sekolah sekolah yang siap bekerja sama dengan mahasiswa KKN. Setelah itu, mengatur jadwal mengajar dengan guru penanggung jawab mata pelajaran yang disepakati. Pengalaman menarik pada kegiatan ini adalah terdapat seorang siswa yang meludah di dalam kelas tatkala mempraktekkan tata cara berwudhu pada bagian memasukkan dan mengeluarkan air ke dalam mulut (kumur-kumur).

Faktor pendukung pada kegiatan ini adalah para pengajar yang bersahabat sehingga membuat peserta didik lebih antusias dalam mengikuti pembelajaran, terlebih lagi saran pembelajaran yang lengkap dan memadai. Kendala yang ditemukan adalah kurangnya komunikasi antara guru penanggung jawab dengan mahasiswi KKN serta jadwal musyawarah mahasiswi KKN yang mendadak sehingga menyebabkan yang bersangkutan tidak bisa mengisi jadwal mengajar pada hari tersebut. Solusinya adalah meningkatkan komunikasi antara guru penanggung jawab dengan mahasiswi KKN serta menyiapkan pengganti dari mahasiswi KKN yang tidak memiliki jadwal pada hari itu atau mengomunikasikan kepada guru yang bertanggung jawab.

\section{Pelatihan Penyelenggaraan Jenazah (PPJ)}

Kegiatan ini berorientasi pada masyarakat umum (beragama Islam) dengan harapan agar masyarakat dapat memahami tata cara penyelenggaraan jenazah sesuai dengan syariat. Kegiatan ini dilaksanakan pada senin, 27 Januari 2020 , Pukul 13.0017.00 WITA di Masjid Miftahussalam, Dusun Samariga.

Kegiatan ini dimulai dengan pembukaan yang dibawakan oleh mahasiswa sebagai MC ke,udian dilanjutkan dengan tilawatil Qur'an oleh mahasiswa KKN. Penyampaian Materi oleh Ustadz Abdullah Abu Ubaidah (Depsos DPD Wahdah Islamiyah Makassar). Pelatihan penyelenggaraan jenazah dibagi menjadi dua bagian, ikhwah dan akhwat. Bagian ikhwah terdiri dari satu kelompok yang dipandu langsung oleh ustadz Abdullah Abu Ubaidah sebagai instruktur. Bagian akhwat terbagi menjadi dua kelompok yang dipandu oleh tim PPJ mahasiswi KKN di setiap kelompoknya.

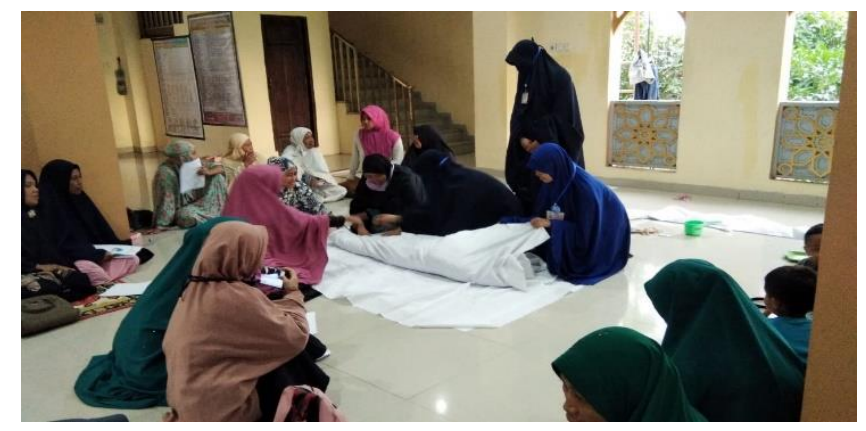

Gambar 1.9. Pelatihan Penyelenggaraan Jenazah 
Kegiatan ini didukung oleh antusias masyarakat selama acara berlangsung serta pengadaan modul sebagai pegangan peserta agar dapat mengikuti alur pelatihan dengan seksama disertai kelengkapan alat peraga PPJ. Kendala yang dijumpai adalah tidak ada trainer dari Muslimah Wahdah Cabang (MWC) Maros yang siap mendampingi tim PPJ mahasiswi KKN desa Baruga karena waktu kegiatan yang padat, kurangnya persiapan serta pengalaman dari tim PPJ mahasiswi KKN Desa Baruga. Solusinya adalah Mengomunikasikan waktu kegiatan dengan pihak MWC Maros dan mempersiapkan tim PPJ secara matang untuk menghadapi berbagai macam kondisi di lapangan.

\section{Silaturahim Akbar dan Pelayanan Kesehatan Gratis}

Sasaran utama kegiatan ini adalah masyarakat umum di Desa Baruga dengan tujuan agar masyarakat dapat mempererat hubungan kekerabatan antar dusun, memperkenalkan pengobatan Tibbun Nabawi dan pelayanan kesehatan secara gratis kepada masyarakat.

Kegiatan ini diaksanakan pada Ahad, 2 Februari 2020, pukul 13.00-17.00 WITA di Masjid Miftahussalam Dusun Samariga, Desa Baruga. Kegiatan ini dimulai dengan pembacaaan ayat suci Alquran dan sambutan dari ketua koordinator Desa Baruga. Selanjutnya pemaparan materi mengenai tibbun nabawi dan dilanjutkan dengan pelayanan kesehatan gratis berupa bekam, cek gula darah dan cek asam urat. Pengalaman menariknya adalah sebagian besar peserta bekam mengganti kuota bekamnya dengan kuota yang lain dengan alasan takut dibekam.

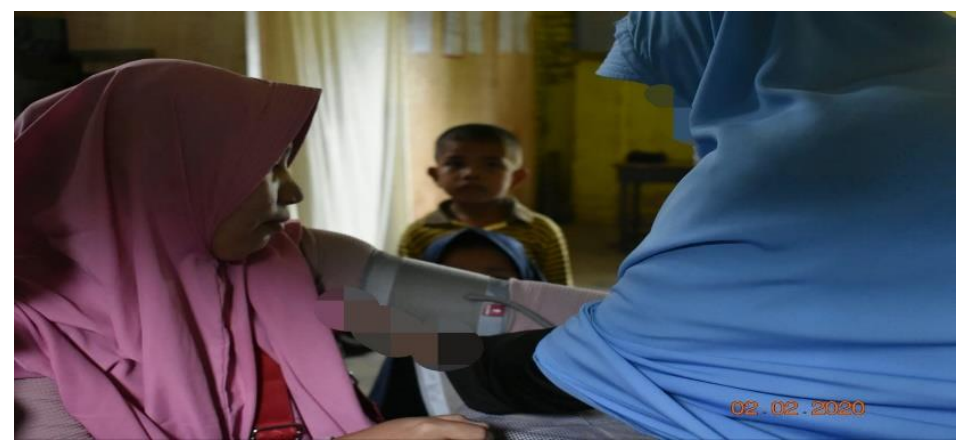

Gambar 1. 10. Silaturahmi Akbar dan Pelayanan Kesehatan Gratis

Faktor pendukung kegiatan ini adalah antusias warga setempat untuk hadir ke acara silaturahmi dan tertibnya peserta pelayanan kesehatan dalam menunggu giliran meskipun cukup lama. Kendala yang dijumpai adalah kurang maksimalnya pemateri dalam membawakan materinya serta perencanaan kegiatan yang kurang maksimal. Solusinya adalah menyiapakan materi dengan baik sebelum kegiatan akan berlangsung, merancang dan merencanakan kegiatan dengan baik, koordinasi dengan pihak terkait dalam pelaksanaan kegiatan serta pembagian tugas pada setiap divisi. 
WAHATUL MUJTAMA': Jurnal Pengabdian Masyarakat

Vol. 1, No. 2 (2020) : Hal. 185-199

Website: https://journal.stiba.ac.id

\section{Festival Anak Sholeh}

Festival Anak Shaleh (FAS) adalah sarana atau wadah untuk mengembangkan bakat yang dimiliki tiap anak dan melatih mental untuk tampil di depan masyarakat. ${ }^{10}$ kegiatan ini berorientasi secara khusus pada anak-anak TPA/TPQ, anak-anak yang masih duduk di bangku Sekolah Dasar (SD) dan masih berusia 10 tahun. Kegiatan ini bertujuan sebagai ajang silaturahmi seluruh anak-anak terkhusus anak-anak TPA/TPQ dan para pengajar dari masing-masing TPA/TPQ, memotivasi anak-anak dalam belajar dan mengembangkan bakat mereka, mendorong generasi penerus bangsa dalam kompetisi bakat pendidikan Islam, menggali prestasi serta potensi anak-anak.

Mahasiswa/i memulai dengan melakukan sosialisasi dengan para pengajar di tiap TPA/TPQ setelah proses pembelajaran selesai dan kepada para orang tua di setiap dusun yang ada di Desa Baruga. Musyawarah dan rapat koordinasi Mahasiswa/i untuk melakukan persiapan dan pembagian tugas di setiap Divisi. Pada kegiatan ini panitia mempersiapkan souvenir untuk anak-anak yang hadir dan mengikuti lomba serta hadiah untuk anak-anak yang berprestasi. Festival Anak Shaleh (FAS) dimulai pada hari Jumat, 07 Februari 2020 yang dimulai pada pukul 14.00 hingga pukul 17.00, yang diawali dengan pembukaan dari Panitia kemudian dilanjutkan dengan lomba pertama yaitu Azan dan MHQ yang disaksikan dengan gembira oleh para pendukung yang disertai yel-yel dari masing-masing perwakilan TPA/TPQ. Pada hari Kedua, Sabtu 08 Februari kegiatan ini dimulai pukul 14.30 dengan cabang perlombaan yaitu, MTQ dan CCI. Hari terakhir, Ahad 09 Februari kegiatan ini dimulai pukul 08.00 dengan cabang lomba CCI babak final, Pildacil serta Rangking 1 yang dilanjutkan dengan pengumuman anak-anak yang berprestasi di tiap cabang perlombaan yang dibarengi dengan menyerahan hadiah dan souvenir.

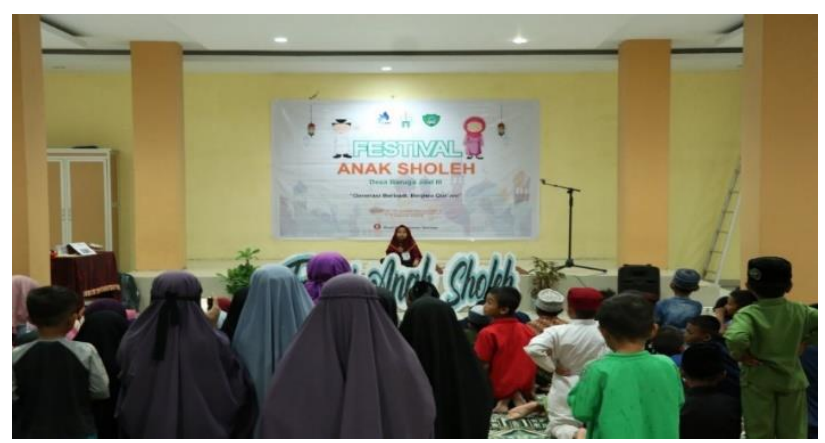

Gambar 1. 11. Festival Anak Saleh

Kegiatan ini didukung oleh antusias anak-anak dalam meramaikan jalannya kegiatan serta respon positif para pengajar tiap-tiap TPA/TPQ dan orang tua santri.

\footnotetext{
${ }^{10}$ Aswar, A., \& Rosmita, R. (2020). Festival Anak Saleh di Desa Leang-leang Kabupaten Maros. WAHATUL MUJTAMA': Jurnal Pengabdian Masyarakat, 1(1), 54-66. Hal 60.
} 
Kendala yang dijumpai pada kegiatan ini adalah minimnya kehadiran dari tokoh masyarakat, acara terlambat dimulai dan keributan yang disebabkan anka-anak keluar masuk masjid. Solusinya adalah memaksimalkan sosialisasi sebelum kegiatan atau memunculkan ide lain agar masyarakat juga dapat berpartisipasi secara maksimal dalam kegiatan ini.

\section{KESIMPULAN}

Dari program KKN III STIBA Makassar desa Baruga, kecamatan Bantimurung, kabupaten Maros, Propinsi Sulawesi Selatan selama kurang lebih 45 hari terhitung sejak tanggal 6 Januari 2020 - 24 Februari 2020 dapat disimpulkan bahwa program ini merupakan amalan tri dharma perguruan tinggi pada pilar pengabdian kepada masyarakat yang telah dirasakan manfaatnya oleh peserta $\mathrm{KKN}$, masyarakat dan pemerintah. Bagi peserta KKN, program ini merupakan ajang untuk melatih dan mengasah kemampuan dalam kegiatan dakwah, kepedulian sosial serta berperan aktif dalam kerja-kerja kolektif bersama masyarakat dan pemerintah. Bagi masyarakat, kehadiran peserta KKN sangat membantu dalam mendalami ilmu agama serta sebagai suplemen pendidikan yang diberikan kepada anak-anak mereka. Bagi pemerintah, program ini sangat membantu dalam pembinaan masyarakat. Program ini telah sukses melaksanakan 11 kegiatan, yaitu: silaturahmi ke rumah warga, taklim muslimah, kajian jumat, DIROSA, pengajaran taḥsīnu qirātil qurāni, jalan santai, ramah tamah, pengajaran agama islam dan bahasa arab, pelatihan penyelenggaraan jenazah, silaturahmi akbar dan pelayanan kesehatan gratis dan festival anak saleh.

\section{DAFTAR PUSTAKA}

Arobi, M. (2019). Rumah-Rumah Tahfizh di Kota Banjarmasin: Profil, Program, dan Metode Pengajaran Al-Qur'an. Tarbiyah: Jurnal Ilmiah Kependidikan, 8(1), 39-52. Hal 39

Aswar, A., \& Rosmita, R. (2020). Festival Anak Saleh di Desa Leang-leang Kabupaten Maros. WAHATUL MUJTAMA': Jurnal Pengabdian Masyarakat, 1(1), 54-66. Hal 60 .

Buku perkembangan penduduk Desa Baruga tahun 2018

Guswenti, M. (2019). Implementasi Metode Dirosa Dalam Pembelajaran Membaca AlQur'an Bagi Santri Di Wahdah Islamiyah Bengkulu (Skripsi, IAIN Bengkulu). Hal.2

Mariam, M. (2019). Peran Majelis Taklim dalam Pemberdayaan untuk Membentuk Kepribadian Muslimah. Lembaran Masyarakat: Jurnal Pengembangan Masyarakat Islam, 5(02), 121-136. 
WAHATUL MUJTAMA': Jurnal Pengabdian Masyarakat

Vol. 1, No. 2 (2020) : Hal. 185-199

Website: https://journal.stiba.ac.id

Saddang, M., Bakar, A. M., Munir. (2018). Implementasi Metode DIROSA dalam Pembelajaran Al-Qur'an Dewan Pimpinan Daerah Wahdah Islamiyah Makassar, (Makassar: Jurnal Diskursus Islam, Vol.6, No.3.

Nadhifa, S. B. (2017). Pemahaman Jamaah Terhadap Pesan Dakwah Ustadz. Abdullah Zaen, Lc., M.A dalam Pengajian Rutin Jum'at Pagi Di Masjid Agung Darussalam Purbalingga (Skripsi, IAIN Purwokerto)

Riswana, R. (2018). Peranan Taklim Muslimah dalam Meningkatkan Pemahaman Hak dan Kedudukan Wanita dalam Rumah Tangga (Studi pada Yayasan Markaz Imam Malik Kota Makassar) (Skripsi, Universitas Islam Negeri Alauddin Makassar).

Widyanto, R. A., Widiyanto, A., \& Arfan, M. Penerapan M-Dakwah Pada Kelompok Kajian Jum'at Pagi Sebagai Sarana Dakwah Alternatif.

Wijaya, H. (2020). Pembelajaran Metode Dirosa di Desa Majannang Kabupaten Gowa. WAHATUL MUJTAMA': Jurnal Pengabdian Masyarakat, 1(1), 67-74. Hal. 70 